\title{
WHAT MAKES FIRMS IN EMERGING MARKETS ATTRACTIVE TO FOREIGN INVESTORS? MICRO-EVIDENCE FROM THE CZECH REPUBLIC
}

\author{
Peter Tóth \\ Petr Zemčík
}
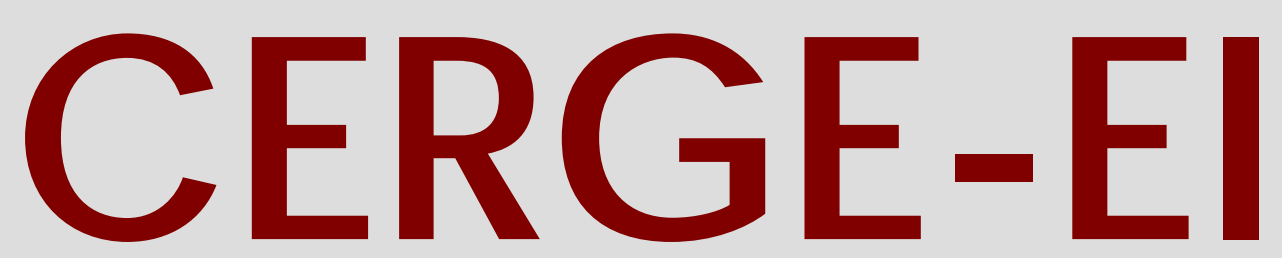

Charles University Centerfor Economic Research and Graduate Education Academy of Sciences of the Czech Republic Ec onomic Institute 


\title{
Working Paper Series 294 (ISSN 1211-3298)
}

What Makes Firms in Emerging Markets Attractive to Foreign Investors?

Micro-evidence from the Czech Republic

\author{
Peter Tóth \\ Petr Zemčík
}

CERGE-EI

Prague, March 2006 
ISBN 80-7343-089-4 (Univerzita Karlova v Praze, CERGE)

ISBN 80-7344-078-4 (Národohospodářský ústav AV ČR, Praha) 


\title{
What Makes Firms in Emerging Markets Attractive to Foreign Investors? Micro-evidence from the Czech Republic
}

\author{
Peter Tóth and Petr Zemčík* \\ CERGE-EI $\dagger$
}

March 2006

\begin{abstract}
We use a panel of Czech firms to enhance existing literature where the dependent variable is foreign ownership. In our estimation, we control for endogeneity and unobserved effects using standard methods complemented by tests for heterogenous Granger-causality. We also model foreign ownership as a response variable in a hazard model and consider sorting by foreign owners rather then by domestic firms. We find that foreigners target firms with a greater ownership concentration in industries's with higher level of risk, in countries with lower labor costs and corporate income taxes.
\end{abstract}

\begin{abstract}
Abstrakt
Používáme panel českých firem k obohacení existující literatury, kde závislá proměnná je zahraniční vlastnictví. V našem odhadu zohledňujeme endogenitu a nepozorované vlivy použitím standardních metod i testu heterogenní Grangerovy kauzality. Zahraniční vlastnictví také modelujeme jako odezvovou proměnnou v hazardním modelu, kde se zahraniční vlastníci namísto domácích třídí do určitých firem. Naše výsledky ukazují, že cizinci se zaměřují na firmy s větší koncentrací vlastnictví, v odvětvích s vyšším rizikem a v zemích s nižšími mzdovými náklady a s nižšími daněmi z př́ijmu korporací.
\end{abstract}

Keywords: foreign ownership, endogeneity, causality, fixed effects, hazard model, truncated sample

JEL classification: G3, F21, C23-C25

\footnotetext{
*Email: petr.zemcik@cerge-ei.cz,peter.toth@cerge-ei.cz,

$\dagger$ A joint workplace of the Center for Economic Research and Graduate Education, Charles University, Prague, and the Economics Institute of the Academy of Sciences of the Czech Republic.

Address: CERGE-EI, P.O. Box 882, Politických vezňů 7, Prague 1, 111 21, Czech Republic
} 


\section{Introduction}

The implications of the ownership structure in general have been well studied in emerging markets, and especially in the Czech environment, which provides an ideal natural experiment of a transition from $100 \%$ state ownership into a wide spectrum of ownership types. The effects of ownership concentration on performance controlling for various types of owners for (mostly newly privatized) firms have been investigated in Djankov (1999) Kočenda (2002), Lízal and Švejnar (2002), Lízal (2002), and Cull, Matesova, and Shirley (2002). The impact of the ownership structure on stock prices (i.e. the firm's value) has been considered for instance by Makhija and Spiro (2000) and Pajuste (2002).

The research studies including foreign ownership as one of the explanatory factors indicate that the presence of foreigners among owners improves performance of the firms. Lízal and Švejnar (2002) find that, based on a number of performance indicators, presence of foreign owners has a positive effect on the long-term performance of former state enterprises. Lízal (2002) demonstrates that foreign presence reduces the probability of bankruptcy and notes that employment in the foreign controlled enterprises has been growing in the late 1990's, and financial indicators have also been superior compared to those of firms with no foreign involvement. Hanousek, Kočenda, and Švejnar (2005) illustrate that the presence of majority foreign ownership has a positive effect on private Czech firms. Sabirianova-Peter, Švejnar, and Terrell (2004) find that foreign-owned firms occupy the top deciles of overall efficiency not only in the Czech Republic but also in Russia. As for stock prices, Makhija and Spiro (2000) conclude that ownership stakes of foreigners are positively related to share values.

Since foreign ownership clearly improves overall performance of Czech (and other) firms, it is of interest to investigate the motives of foreigners behind their investment in the Czech Republic and hence reverse causality of the studies cited 
above. The voucher privatization provided the first opportunity to investigate what causes a foreign investor to invest in a Czech company, and once she invests, what is the typical magnitude of ownership. Anderson, Jandík, and Makhija (2001) find that foreigners preferred safe and profitable firms, which did not have shares reserved for Czech insiders. Furthermore, the structure and size of the foreign investor's equity stake decreased with profitability and a high degree of tangible assets and increased with the level of indebtedness and the variability of industry profitability. By definition, the sample of data used in Anderson, Jandík, and Makhija (2001) consists of firms participating in the voucher privatization process. The choice is given by the fact that some basic accounting data were made available to investors by the Center for Voucher Privatization of the Czech Ministry of Finance. The nature of the data provides basis for a simple cross-sectional analysis with only 41 foreign-owned firms. This dataset can be significantly enhanced due to the fact that high quality accounting data have been collected for a large number of firms, and the sample is not limited to the firms included in the first wave of privatization. The data have been recorded at annual frequency and we can make use of panel data techniques.

We use a panel data of Czech firms, most of which are not listed on the Prague Stock of Exchange. We relate foreign ownership in a firm to various macroeconomic and firm specific variables. The macroeconomic variables include investor sentiment ${ }^{1}$ corporate income tax, labor costs, and labor intensity differentials between the Czech Republic and the home country of foreign stakeholders (see Kulawczuk, Bak, and Szczesniak 2004). The firm-level characteristics contain various measures of profitability, risk, size, ownership concentration, market share, etc. The variable of interest is the foreign stake in a given firm. While previous studies (e.g. Sabirianova-Peter, Švejnar, and Terrell 2004) only used a dummy indicating for-

\footnotetext{
${ }^{1}$ Sokalska (2001) defines the international investor sentiment as an unobservable variable approximating joint movements of equity markets in Poland, Hungary, and the Czech Republic.
} 
eign ownership greater than $50 \%$, we are able to extract more detailed information regarding foreign stakeholders, namely their percentage stakes in the company and countries of origin.

This additional information together with panel structure of our dataset helps us to extend research where the dependent variable is foreign ownership in a number of ways. We test for Granger causality of the dependent variable and potentially endogenous explanatory variables. Our candidates for endogenous variables are ownership concentration and the industry's volatility of the accounting rate of return (our measure of systemic risk). We use new panel data tests for heterogenous Granger-causality proposed in Hurlin (2004) which are suitable for data with a short time-series dimension. We find that foreign ownership Granger causes both variables and vice versa which is consistent with our prior of their endogeneity. In our subsequent estimation, we control for this endogeneity and account for unobserved effects, neither of which was a part of the analysis in Anderson, Jandík, and Makhija (2001).

For the sake of robustness, we employ several econometric techniques in our estimation of the impact of macro and firm-level variables. Namely, we estimate a linear model by OLS as a benchmark, use fixed effects and first differences transformations, and then apply 2SLS. In addition, we consider panel data versions of limited dependent variable probit and logit models and a corner solution panel data Tobit. Based on some specification tests and taking into account limitations of our data, we center our attention on results from fixed-effects-2SLS and first-differences linear models. However, our estimates are mostly robust to the use of a particular estimation strategy.

Our results indicate that macro variables such as international investor sentiment and employment compensation, labor costs and corporate tax differentials all have a positive impact on stakes of foreigners. The strong effect of the differen- 
tials echoes the notion that profitability of marginal investment by foreign firms increases by investing abroad (see Kulawczuk, Bak, and Szczesniak 2004). From firm specific variables, increases in the standard deviation of a firm's industry's rate of return, ownership concentration, size and industry share imply an increase in foreign ownership.

We further examine our data using different prospectives. We start with an attempt to answer a question of what makes domestic firms to be a more likely target of foreigners. We use a proportional hazard model to estimate probability of a switch from a zero foreign ownership to a positive one. Foreign ownership is hence viewed in the terms of duration, similarly to literature on unemployment. Due to data limitations, we assume single-spell data and time-invariant covariates. Conditional on a foreign investor purchasing a share in a Czech firm, foreign investors still prefer large firms with high ownership concentration, in an industry with a greater variability of profitability.

Finally, we consider a foreign owner (rather than a foreign owned firm) to be our sorting criterion for a dependent variable. We thus form a truncated sample of stakes of foreign investors with corresponding explanatory variables. The sample is truncated because we do not possess any information regarding foreign firms which have decided not to purchase a company share of a firm in the Czech Republic. The pooled OLS again show significance of coefficients on the industry systemic risk and ownership concentration. Interestingly, the impact of macro variables is limited in this case.

The remainder of the paper is organized as follows. Section 2 motivates used explanatory variables, Section 3 describes our data and their source, Section 4 characterizes the employed econometric techniques and analyzes the results, and Section 5 concludes. 


\section{Determinants of Foreign Ownership}

In this section, we characterize general features of a firm, which might make it more attractive to foreign investors. We divide these characteristics into two groups, firm-level variables and macro-level variables, respectively. We formulate our predictions based on a combination of theory, common sense, and previous empirical observations. We adopt a perspective of a foreign firm, which is trying to maximize Net Present Value of its investments, some of which may take place abroad. Many of the variables are inspired by the literature on portfolio investment. As many of the firms in our data are not listed on any stock exchange, we employ various analogies of the standard stock market related variables. Our predictions will be tested on Czech data using cross-sectional and panel data estimation methods in Section 4.

\subsection{Firm-level Determinants}

\section{Profitability}

Profitable firms tend to be more attractive and hence preferred by foreign investors. There are several potential measures of profitability. We use the accounting rate of return (ARR) defined as the annual average of net income to book value of shareholder's equity. An alternative for firms listed on the stock exchange is the $\mathrm{B} / \mathrm{M}$ ratio, defined as the book value of equity divided by the market value of equity at the end of the fiscal year. Typically, growth firms are associated with a low $\mathrm{B} / \mathrm{M}$ ratio while the value firms have a high $\mathrm{B} / \mathrm{M}$ ratio. Using the results in Fama and French (1995), B/M can be substituted by ARR for firms not listed on any stock exchange.

\section{Risk}

Risk considerations are somewhat more complex. To compensate for various costs 
related to cross-border investment, a foreign investor might be willing to accept a higher level of risk provided it is priced properly, i.e. higher risk is associated with the higher rate of return. Therefore, foreign investors prefer firms with lower idiosyncratic and higher systemic risk. The standard stock market measures of systemic and idiosyncratic risks are based on the estimation of the market model, in which a firm's daily excess return is regressed on the daily excess return on the market portfolio. The estimated coefficient is the measure of systemic risk beta and the residual variance from the regression is the measure of idiosyncratic risk. However, these measures cannot be used in our case as only a very small number of firms is listed on the Prague Stock Exchange. One possible proxy for systemic risk of non-listed firms is the intra-industry variance of ARR. The idiosyncratic risk for individual firms is well characterized by the data on capital structure, which describe the financial health of the company. Long term financial distress is captured for example by the ratio of total liabilities to total assets (the leverage

ratio). The short term financial distress is reflected in the current ratio i.e. the ratio of current assets to current liabilities at the end of a fiscal year.A company's solvency is characterized by the ratio of the cash-flow to the market value of equity (or the book value).

\section{Firm Size}

Contrary to predictions of standard finance models such as the capital asset pricing model, size explains a large portion of both cross-sectional and time-series variation in returns (see Fama and French 1992, 1993 for the summary of existing literature and extensive empirical analysis). Moreover, greater size may be cause firms to be well-known abroad, which in turn stimulates foreign investment - see Kang and Stultz (1997), Dahlquist and Robertsson (2001), and Lin and Shiu (2003). The size is significant in all these studies, even after accounting for other firm's characteristics. Also, large firms are more likely to be successful in utilizing the 
expertise and capital of foreign investors. Hence, we are likely to observe that foreign investors target larger firms. We measure size as the total book value of firms' assets.

\section{Ownership Concentration}

In an environment, where minority owners are not well protected and where acquiring a portion of a domestic company requires a lot of investment in terms of opportunity costs, foreigners are likely to target a controlling share of the company i.e. greater than $50 \% .^{2}$

\section{Market Share}

It is also likely that foreigners tend to purchase domestic firms to get access to a local market. In this case, they tend to prefer local firms with higher market shares.

\section{Other Factors}

Here we include variables, which are difficult to fit into other categories, such as staff costs per sales, value added per sales, etc. Staff costs per sales are likely to play a role for firms from developed countries investing in emerging economies. We will discuss this issue below in some detail when we comment on the role of average employee compensation. Value added is typically going to be high in industries with a qualified labor force. For example, a German firm may buy a controlling share in a Czech firm in the same industry when it can expect lower labor costs for relatively highly qualified labor.

While there are other candidates for the firm-level factors (e.g. high export ratios), we do not mention them here due to restricted data availability.

\footnotetext{
${ }^{2}$ In the Czech Republic, this relationship is likely to be even stronger in the near future. In May 2005, §813 of the Czech Business Code was amended to allow forced buy-outs of minority shareholders by shareholders owning $95 \%$ and more of a given company.
} 


\subsection{Macro-level Determinants}

\section{International Investor Sentiment}

This variable is inspired by Sokalska (2001) who defines the international investor sentiment as an estimated state variable from a Markov chain model. The Markov chain is estimated using data on equity returns fron the Czech Republic, Hungary, and Poland. The selection of the three countries is given partly by availability of the data and partly by the fact that they are considered leaders in the region. The stock market indices from the stock exchanges in Prague, Budapest, and Warsaw move closely together. The impact of the local macroeconomic fundamentals is rather small, perhaps due to small capitalization, volume of trading, and liquidity. Sokalska (2001) documents that the estimated process is correlated with global macroeconomic fundamentals, from the US term structure to emerging markets indices.

While one can only speculate on the relative importance of this latent variable as compared to the firm level determinants of foreign ownership, the following hypothesis can be formulated: The more favorable the global investment climate, the higher foreign ownership. To avoid issues connected with selection of a correct specification for the Markov chain process, we construct a simple variable based on monthly movements of the three stock markets. First, we define a dummy for each market, with the dummy being equal to one if the stock market in question is above its long-term average on a given month. The average of monthly sums in a given year gives us a desired proxy for the international investor sentiment.

\section{Corporate Income Tax and Labor Costs}

Foreign investors may be interested in buying a share in domestic enterprises if they can save either on taxes or on labor costs as compared to their home countries. Kulawczuk, Bak, and Szczesniak (2004) formalize this idea and construct an index, which characterizes additional profitability of a firm investing abroad. The index 
is based on the assumption of the foreign investor being able to achieve the same level of productivity in a targeted company as in her base country and considers differences in both corporate income taxes and labor costs between two countries, the home country of the foreign investor and the country where she invests.

We split the two effects and analyze them separately. Our dataset of Czech firms allows us to identify a country of origin for foreign owners. Using regression analysis, we estimate the effects of corporate income tax and labor cost differentials. We use statutory corporate income taxes and various measures of labor costs and also include labor intensity of the base country.

\section{Data}

We use an unbalanced panel of Czech firms from all economic sectors. The data was collected by Aspekt s.r.o. starting from 1993. The largest part of our sample consists of firms in manufacturing and trade. The sample period starts in 1997 and ends in 2002, with only a few observations in 2002. The maximum number of annual observations is 1979 firms in year 2000. We restrict our sample to 1997 onwards due to availability of some of the macro-level variables and because the number of firms is small before 1997.

The variables are defined in Appendix A. Descriptive statistics for the firm-level variables are respectively given in Table 1 for the whole panel and in Tables 2, 3, and 4 for cross sectional data by years. Several patterns emerge. From 1997 until 2002, the size of firms in terms of total assets increased with annual growth rates exceeding inflation. To eliminate the effect of inflation, we adjust variables with Czech crowns as a unit of measurement to inflation using CPI from the Czech Statistical Office (base year 2000). Profitability measured by the accounting rate of return decreased over the observed time period, from $24.29 \%$ to $8.13 \%$. Figure 1 
shows the histogram in percentages. Lower profitability may be a sign of a maturing market in the Czech Republic and the tendency of the Czech firms to invest in projects with a lower level of risk (approximated by the standard deviation of the industries' accounting rates of return, indsarr). Indebtness (see variable lever) decreased as well, suggesting that firms relied more on internal resources for growth. Current ratio and cash-flows per sales vary from firm to firm, and over time, the solvency rate decreased over the considered time-period. Staff costs per sales, value added per sale, and Herfindahl index of ownership concentration started at lower values, increased, and stabilized at their long-term mean values around 6000 .

The variable of interest is the share of registered capital owned by foreigners. Studies on Czech firms using foreign ownership as a dependent variable have only been able to distinguish between foreign ownership greater or smaller than $50 \%$ (e.g. Sabirianova-Peter, Švejnar, and Terrell 2004). The distinction is made at the level of the Czech Statistical Office. However, we are able to enhance this information in several ways. Using the Aspekt database, we determine the exact percentage of each firm owned by foreigners and their countries of origin. We then track changes in the percentage through time. We are not aware of any study, which uses a finer description of foreign ownership in emerging markets. The descriptive statistics for the whole sample and by years are reported in Tables $1,2,3$, and 4 , respectively. The level of foreign ownership was had been increasing steadily since 1997 (8.53\%) until $2002(12.42 \%)$. Figure 2 shows the histogram of foreign ownership for the whole sample. We can see that most of the data points are concentrated at 0 and then at $100 \%$. The distribution of only positive values is displayed in Figure 3 . The more detailed view indicates higher accumulation of foreign ownership for values greater than $50 \%$ i.e. stakes allowing to control a given company.

The group of macro-level explanatory variables consists of the investor sentiment, labor costs per value added in manufacturing, the employee compensation 
rate, and corporate income taxes. The investor sentiment (Table 6) greater than 1.5 indicates that regional stock markets have been mostly increasing during a given year (see Table 5). Labor costs per value added in manufacturing are typically lower in new member countries of the European Union (Table 7). The employee overall compensation rate is higher in most countries investing in the Czech Republic (exceptions are either new members of the EU or less developed countries). Finally, corporate income tax rates in Table 8 are on average lower in new member countries, and there is an overall tendency to decrease the rates.

\section{Estimation}

In this section, we investigate the determinants of foreign ownership from several perspectives. First, to examine interaction between the dependent variable and (potentially) endogenous explanatory variables, we test for causality using a technique suitable for panel data with a short time span. Second, we estimate a linear model (LM) with the stakes of foreigners as a dependent variable. We account for unobserved effects and endogeneity by first differences (FD) and fixed effects (FE) models in combination with 2 SLS. Then we employ limited dependent variable probit and logit panel data models complemented by a corner response Tobit panel data model. Third, we use a hazard model to find what makes domestic firms likely to be targeted by foreigners. Finally, we estimate a truncated regression model where the focus is on foreign owners rather then foreign owned firms.

\section{Causality}

First, we would like to investigate the direction of causality between the dependent and two candidates for endogenous explanatory variables, respectively the ownership concentration and the standard deviation of the accounting rate of return in an 
industry. The high ownership concentration makes a domestic firm an easier target since a foreign investor needs to negotiate with a smaller number of owners. The variability of rate of return is almost surely affected by the entrance of foreigners, and it is possible that high systemic risk industries are targeted more often since the variability of the foreign acquirerer's profit is likely to be lower. While causality and endogeneity are obviously not identical concepts, evidence of causality is symptomatic for the presence of endogeneity between stakes of foreigners and the two above-mentioned variables. A suitable test for Granger causality in panel data with a short time-series dimension is proposed in Hurlin (2004) and implemented in Hurlin and Venet (2004).

Consider two stationary variables, $y$ and $x_{j}$, and the following linear model:

$$
y_{i t}=a_{i}+\sum_{l=1}^{L} \gamma_{i}^{(l)} y_{i, t-l}+\sum_{l=1}^{L} \delta_{i}^{(l)} x_{i, j, t-l}+\epsilon_{i t}
$$

where $e_{i t}$ are normally i.i.d. with zero mean and finite heterogeneous variances and $\epsilon_{i}=\left(\epsilon_{i 1}, \ldots, \epsilon_{i T}\right)^{\prime}$ are independently distributed across groups. The null hypothesis of the Homogeneous Non Causality (HNC) is:

$$
H_{0}: \delta_{i}=0, \quad \forall i=1, \ldots, N
$$

where $\delta_{i}=\left(\delta_{i}^{(1)}, \ldots, \delta_{i}^{(L)}\right)^{\prime}$. The alternative hypothesis allows for $N_{1}$ individual units with no causality and for heterogeneous causality among the rest of the units. It is defined as:

$$
\begin{aligned}
H_{1}: & \delta_{i}=0, \quad \forall i=1, \ldots, N_{1}, \\
\delta_{i} & \neq 0, \quad \forall i=N_{1}+1, \ldots, N,
\end{aligned}
$$

where $N_{1} \in[0, N)$ is not known. Let $W_{i t}$ denote the Wald statistic associated with the individual test of $H_{0}$ for each $i=1, \ldots, N$, and let $W_{N T}^{H N C}=(1 / N) \sum_{i=1}^{N} W_{i T}$. Hurlin (2004) proves that for a fixed $T>5+2 L$, the approximated standardized 
statistic

$$
Z_{N T}^{H N C}=\sqrt{\frac{N}{2 \times L} \times \frac{(T-2 L-5)}{(T-L-3)}} \times\left[\frac{(T-2 L-3)}{(T-2 L-1)} W_{N T}^{H N C}-L\right]
$$

converges in distribution to $N(0,1)$ as $N \rightarrow \infty$.

In the context of our research problem, $y$ is foreign ownership and $x_{j}$ is an explanatory variable of interest. We first verify stationarity by a panel data unit root test suggested in Im, Pesaran, and Shin (2003) and then investigate causality in both directions using the statistic (4), which can be easily applied to non-balanced panels. We only consider the lag $L=1$ to meet the requirement of at least 8 observations, which we achieve by considering a longer time span than 1997-2002. The number of firms is not an issue in this case as we need 8 subsequent observations for each firm at any starting in any year from 1993 to 1996.

Evidence from panel data unit root tests, according the $Z_{t-b a r}$ statistic from Im, Pesaran, and Shin (2003), is somewhat mixed and depends on the inclusion of a time trend. For example, the null hypothesis of a unit root is rejected for fshare when trend is not included (see Table 9), and it is rejected otherwise. The results are reversed for herfin. Since both of these variables are restricted with respective intervals from 0 to 1 , and from 0 to 10,000 we view the two variables as stationary. For insdarr, the null is strongly rejected with no trend included and almost rejected at $10 \%$ level of significance, and hence, we consider it stationary as well. The results of causality tests are reported in Table 10. Foreign ownership is Granger-caused by the Herfindahl index and vice versa. We get similar results for foreign ownership and the industries' standard deviation of ARR. Presence of Granger causality indicates endogeneity among the investigated variables.

\section{Foreign Stakes: A Standard Approach}

We model the foreign ownership as the dependent variable $\left(y_{i t}\right)$ and the firm and 
macro characteristics as the explanatory variables $\left(x_{i t}\right.$ 's), respectively. The estimated regression model then is:

$$
y_{i t}=\beta_{0}+\beta_{1} t+\beta_{2} x_{i 1 t}+\ldots+\beta_{k} x_{i k t}+v_{i t}, \quad i=1, \ldots, n, t=1, \ldots, k,
$$

where

$$
v_{i t}=a_{i}+u_{i t}
$$

We take logs for explanatory variables in the Czech currency such as total assets and relate others to sales when they can be negative to increase the number of observations (e.g. cash flows). The estimation of coefficients in (5) involves two challenges - endogeneity of some variables and treatment of the unobserved effect $a_{i}$. To handle endogeneity, we use 2SLS. The Herfindahl index and the industries' standard deviation of ARR are our endogenous variables. As instruments we use exogenous variables and lagged endogenous variables. We consider several potential properties of the error term $v_{i t}$ and use corresponding estimation methods. If $a_{i}$ is correlated with some of $x$ 's, one can employ fixed effects or first-difference estimators, and if $a_{i}$ is uncorrelated with explanatory variables, we can use the random effects estimator. In effect, we are using the 2SLS generalizations of simple panel data methods in the case of exogenous variables.

The Hausman specification test (see Table 11) rejects the the null hypothesis of the random effects model, and hence, we only report the results of the estimation of fixed effects models (LM-FE and LM-FE-2SLS) with a pooled OLS estimation of the LM as a reference (LM-OLS) - see Table 12. The Hausman test also rejects LM-FE in favor of the alternative LM-FE-2SLS. Since both models suffer from some minor but significant residual autocorrelation, we also estimate LM in first differences with results in Table 13 (LM-FD and LM-FD-2SLS). The price for robustness with respect to autocorrelation is a smaller number of observations. 
Here the Hausman test cannot reject $H_{0}$ : LM-FD and hence, we view LM-FD as preferable to LM-FD-2SLS. To summarize, our discussion of results will rely on the estimates of LM-FE-2SLS and LM-FD though there seems to be only minor quantitative differences across the used methods.

The macro variables are all significant and positive as hypothesized with the exception of the corporate tax differential in LM-FD, which is significantly negative, contrary to expectations. However, there maybe a downward bias in the case of FD. If taxes in a foreign country increase relative to the Czech Republic, foreign investors can start building new factories there. This is not captured by firstdifferenced data, which only use already existing firms since the first differences are not available for the new ones. In general, there maybe another reason for a weak impact of corporate taxes; double taxation can reduce corporate tax differentials among countries.

Among the firm level variables, coefficients on the volatility of the accounting rate of return and the Herfindahl index of concentration are positive and significant in both LM-FE-2SLS and LM-FD. The positive coefficient for the industry's volatility supports the view that foreigners tend to focus on the industries with a high level of risk. This view is also consistent with our previous tests since high insdarr Granger causes $f$ share. ${ }^{3}$ The estimate of the coefficient for the index of concentration suggests that foreigners target firms with higher ownership concentration perhaps because they are easier to acquire. ${ }^{4}$ Our estimation of hazard models below should shed more light on the mutual relationship between foreign ownership on the one hand and volatility of profits and ownership concentration on the other. In the LM-FE-2SLS, estimates of coefficients for solvency, real assets, and industry's share are significant. The estimate is negative for solvency and positive for

\footnotetext{
${ }^{3}$ Obviously, the $f$ share also has a consequent impact on insdarr.

${ }^{4}$ As was the case with the industry's standard deviation of ARR, the concentration changes after the foreigner purchases a stake in the company.
} 
the other two variables. While these estimates are not significant in LM-FD, they have the same sign as in LM-FE-2SLS. The estimate for the solvency coefficient is too small to be economically meaningful, but the other two estimates provide some evidence of foreigners purchasing bigger firms with high industry shares.

While the majority of values predicted by the linear model for foreign share $\hat{y}_{i t}$ lie within the range of 0 and 1 with a higher frequency at 0 , there are values lower than 0 and greater than 1, leading us to consider other ways of modelling the limited dependent variable as a robustness check of our results from the LM estimation. Based on histogram 2, we can model the dependent variable as discrete i.e. $y_{i t}=0$ for a firm $i$ without a foreign owner at time $t$ and $y_{i t}=1$ otherwise. $y_{i t}=0$ if $y_{i t}^{*}>0$ and $y_{i t}=1$ if $y_{i t}^{*} \leq 0$ where

$y_{i t}^{*}=\beta_{0}+\beta_{1} t+\beta_{2} x_{i 1 t}+\ldots+\beta_{k} x_{i k t}+v_{i t}=x_{i t}^{\prime} \beta+v_{i t},=i=1, \ldots, N, t=1, \ldots, T$,

with $v_{i t}$ defined in (6). For the fixed effect model,

$$
\operatorname{Pr}\left[y_{i t}=1\right]=\operatorname{Pr}\left[y_{i t}^{*}>0\right]=\operatorname{Pr}\left[u_{i t}>-x_{i t}^{\prime} \beta-a_{i}\right]=F\left(x_{i t} \beta+a_{i}\right) .
$$

The density function is logistic in the case of the logit model and normal in the case of the probit model. The presence of $a_{i}$ complicates the estimation; the computational burden can be reduced by obtaining the conditional likelihood for the logit model. A similar reduction is not possible for the normal density, and hence, it is standard to estimate only the random effects probit model (see Baltagi 2005). The conditional fixed effects logit (Lo-FE) and random effects probit (Pro-RE) estimates are reported in Table 14. Assuming again that our dependent variable is continuous, we can use the Tobit model, which is well-suited for corner-solution responses (foreign ownership $=0$ ). The fixed effect Tobit is not estimated due to problems similar to those in the probit estimation. Therefore, we report only random effects 
Tobit (To-RE) estimates, also in Table 14. There are some shortcomings to these models. None of them account for endogeneity, which would make our estimation very complex and sensitive to various assumptions. Also, Pro-RE and T-RE ignore potential correlation between $a_{i}$ 's and explanatory variables.

In spite of these issues, conclusions based on the estimation of probit, logit, and Tobit models are roughly consistent with our results based on the LM. The coeficients estimates for macro variables have the expected sign when they are significant. The index of concentration and industry's share have significantly positive coefficients in all the regression models. Solvency's coefficient is either 0 or significantly negative as before, and the coefficient of industry's level of risk has a plus sign in all models and is significant in two cases.

\section{Firms: A Hazard Model}

Here, we treat foreign ownership as a response variable in the form of duration. We follow a firm and record when there is a change of foreign ownership state from 0 to positive. Then we estimate the probability of this change conditional on firm characteristics. Since the time dimension of our data is limited and time-varying models typically require strict exogeneity of variables, we focus on a model with a hazard function conditional on time-invariant covariates. We also assume that we have only single-spell data.

Let $S$ be the period during which the change occurs. The conditional hazard function is

$$
\lambda(t ; \mathbf{x})=\lim _{h \downarrow 0} \frac{(t \leq S<t+h \mid S \geq t, \mathbf{x})}{h}
$$

where $\mathbf{x}$ is the vector of explanatory variables. We assume that

$$
\lambda(t ; \mathbf{x})=\kappa(\mathbf{x}) \lambda_{0}(t),
$$


where $\kappa(\mathbf{x})>0$ and $\lambda_{0}(t)>0$ is the baseline hazard. This is a proportional hazard model. $\kappa(\mathbf{x})=\exp (\mathbf{x} \beta)$. We estimate $\beta$ using the Cox (1972) approach. We only consider firm-specific variables and calculate standard errors robust to clustering on foreign ownership.

Results are reported in Table 15. Conditional on a decision to acquire a firm in the Czech Republic, foreigners seem to target larger firms with a higher ownership concentration and size in industries with a higher volatility of profits. In other words, the probability of a firm becoming owned at least partially by foreigners increases with the significant variables. The results support the view that foreign owners target firms with a higher level of risk. While their entrance can also increase the volatility by entering the Czech market, we cannot evaluate this hypothesis in the used hazard model. Foreigners also prefer firms with a higher ownership concentration, and we again cannot comment on whether their entrance increases the concentration or not.

\section{Foreign Stakeholders}

Here we attempt to find out what makes investors invest abroad. Data units are now selected by foreign owners. The dependant variable is a stake of a foreigner. The explanatory variables are macro variables and characteristics of the firm in which she owns a share. Obviously, we only have a truncated sample of foreign owners since we do not have any information for foreigners who did not invest abroad. We only use pooled OLS due to a small number of observations and technical difficulties connected with robustness to endogeneity, and unobserved fixed effects in panel data truncated regression models. Therefore, our estimates in Table 16 have to be treated with some caution. The industry's variability of profit and ownership concentration are again significant. 


\section{Summary}

We investigate the determinants of foreign ownership using panel data on firms in the Czech Republic. We first investigate the mutual relationship between foreign ownership and two potentially endogenous variables: the Herfindahl index of concentration and the variability of industry's profit. Foreign ownership helps to predict the two variables and vice versa. Granger-causality in both directions can be interpreted as an indication of endogeneity. We proceed to evaluate the impact of various macro- and firm-level variables on the foreign share in a firm using a variety of econometric methods. We account for both endogeneity and unobservable fixed effects and employ a number of limited dependent variable and corner solution models. Share of foreigners in Czech firms are affected both by macroeconomic and firm-level factors. The macroeconomic factors with a positive impact on foreign ownership include international investor sentiment, differentials in labor costs, employee compensation, and corporate taxes across countries. On the other hand, important firm characteristics are variability of profit in the firm's industry, size, ownership concentration, and industry share.

The next step in our empirical investigation is an adoption of a novel perspective on how to study the effects of various factors on shares of foreigners in domestic firms. We follow each firm and record the moment when it becomes at least partially

owned by foreigners. By re-organizing the data in this manner, we can use the Cox hazard model to estimate the probability of the firm being foreign owned conditional on the foreigner's decision to purchase a Czech firm. Attractive targets are large in size, with high ownership concentration and industry risk. Yet another novel way to use our data is to sort foreign ownership percentages by foreign owners and not by firms. The truncated sample of 
foreigners then can be used to quantify the effects of our macro and micro factors. Again, the factors with strong impact are the Herfindahl index of concentration and the standard deviation of the industry's rate of return. 


\section{References}

Anderson, C., T. Jandík, and A. K. Makhija (2001) "Determinants of Foreign Ownership in Newly Privatized Companies in Transition Economies," Financial Review, Vol 36(2), pp. 161-175.

Baltagi, B. H., (2005) Econometric Analysis of Panel Data. 3rd ed, John Wiley \& Sons, Ltd., Chichester, England.

Cull, R., J. Matesova, and M. M. Shirley (2002) "Ownership and the Temptation to Loot: Evidence from Privatized Firms in the Czech Republic," Journal of Comparative Economics, Vol. 30, pp. 1-24.

Cox, D.R. (1972) "Regression Models and Life Tables," Journal of the Royal Statistical Society, Series B, 34, 187-220.

Dahlquist, M. and G. Robertsson (2001) "Direct Foreign Ownership, Institutional Investors, and Firm Characteristics," Journal of Financial Economics, Vol. 59, pp. 413-440.

den Haan , W. and A. Levin (1997) "A Practitioner's guide to Robust Covariance Estimation, " in G. Maddala and C. Rao (eds) Handbook of Statistics, Vol. 15, Elsevier Science, North-Holland: Amsterdam, Holland.

Djankov, S. (1999) "Ownership Structure and Enterprise Restructuring in Six Newly Independent States," Comparative Economic Studies, Vol 41(1), pp. 75-95.

Driffill, J. and M. Sola (1993) "Intrinsic Bubbles and Regime Switching," Working Paper, Birkbeck College.

Fama E. F. and K. R. French (1992) "The Cross-Section of Expected Stock Returns," The Journal of Finance, Vol. 47, pp. 427-465. 
Fama E. F. and K. R. French (1993) "Common Risk Factors in the Returns on Stocks and Bonds," Journal of Financial Economics, Vol. 33, pp. 3-55.

Fama E. F. and K. R. French (1995) "Size and Book-to-Market Factors in Earnings and Returns," The Journal of Finance, Vol. 50, pp. 131-155.

Gilbert S. and P. Zemčík (2002) "Can Beta-Pricing Models Explain Performance Differences Among Assets?" Southern Illinois University Carbondale, No. 0204.

Green, W. H. (1997) Econometric Analysis. Prentice-Hall, New Jersey.

Hamilton, J. D. (1989) "A New Approach to the Economic Analysis of the Nonstationary Time Series and the Business Cycle, " Econometrica, Vol. 57(2), pp. $357-384$.

Hamilton, J. D. (1990) "Analysis of Time Series Subject to Changes in Regime," Journal of Econometrics, Vol. 45, pp. 39-70.

Hamilton, J. D. (1994) Time Series Analysis. Princeton University Press, New Jersey.

Hamilton, J. D. and G. Lin (1996) "Stock Market Volatility and the Business Cycle," Journal of Applied Econometrics, Vol. 11, pp. 573-593.

Hamilton, J. D. and R. Susmel (1993) "Autoregressive Conditional Heteroskedasticity and Changes in Regime," Journal of Econometrics, Vol. 64, pp. 307333.

Hanousek, J. and R. K. Filer (2000) "The Relationship Between Economic Factors and Equity Markets in Central Europe," Economics of Transition, Vol. 8, No. 3, pp. 623-638. 
Hanousek, J., E. Kočenda, and J. Švejnar (2005) "Origin and Concentration: Corporate Ownersip, Control, and Performance," Working Paper 259, CERGEEI, Prague.

Hurlin, Ch. (2004) "Testing Granger Causality in Hetergoeneous Panel Data Models with Fixed Coefficients," Working Paper 2004-05, Laboratoire d'Economie d'Orléans.

Hurlin, Ch. and B. Venet (2004) "Financial Development and Growth: A ReExamination Using a Panel Granger Causality Test," Working Paper 2004-18, Laboratoire d'Economie d'Orléans.

Im, K.S., M.H. Pesaran, and Y. Shin (2003) "Testing for Unit Roots in Heterogeneous Panels," Journal of Econometrics 115, pp.53-74.

Kang, J. K. and R. M. Stultz (1997) "Why is There a Home Bias: An Analysis of Foreign Portfolio Equity Ownership in Japan, " Journal of Financial Economics, Vol. 46, pp. 3-28.

Kočenda, E. (2002) "Development of Ownership Structure and its Effect on Performance: Czech Firms from Mass Privatization," CEPR Discussion Paper, No. 3139.

Kulawczuk, P., M. Bak, and A. Szczesniak (2004) "Tax and Social Labor Cost Competition in central Europe in European Union Pre-Accession period," Global Development Network.

Lin, C. H. and C. Shiu (2003) "Foreign Ownership in the Taiwan Stock Market - An Empirical Analysis," Journal of Multinational Financial Management, Vol 13(1), pp. 19-41.

Lízal, L. (2002) "Determinants of Financial Distress: What Drives Bankruptcy 
in a Transition Economy? The Czech Republic Case," Working Paper, the William Davidson Institute 451.

Lízal, L. and J. Švejnar (2002) "Privatization Revisited: The Effects of Foreign and Domestic Owners on Corporate Governance," CERGE-EI Discussion Paper, No. 89.

Makhija, A. K. and M. Spiro (2000) "Ownership Structure as a Determinant of Firm Value: Evidence from Newly Privatized Czech Firms," The Financial Review, Vol. 41, pp. 1-32.

Pajuste, A. (2002) "Corporate Governance and Stock Market Performance in Central and Eastern Europe: A Study of Nine Countries, 1994-2001," Working Paper, Stockholm School of Economics.

Sabirianova-Peter, K., J. Švejnar, and K. Terrell (2004) "Foreign Investment, Corporate Ownership, and development: Are Firms in Emerging Markets Catching Up to the World Standard?" Working Paper, University of Michigan.

Sokalska, M. (2001) "What Drives Equity Returns in central and Eastern Europe," Working Paper, Warsaw School of Economics.

Sawicki, J. and J. Hric (2001) "Arbitrage Opportunities in Parallel Markets: The Case of the Czech Republic," Working Paper, EFMA 2001 Lugano Meetings.

White, H. (1980) "A Heteroskedasticity-consistent Covariance Matrix Estimator and a Direct Test for Heteroskedasticity," Econometrica, Vol. 48, pp. 817838. 


\title{
Appendix A - Data Definitions
}

\author{
A.1. Firm-level Variables: \\ logrta - logarithm of real total assets \\ arrps- accounting rate of return (operating profits over registered capital) per sales \\ lever - leverage: liabilities over total assets \\ current - current ratio: current assets over current liabilities \\ cashflps - cash-flow (or annual change in cash stock if the first is not available) per \\ sales \\ solvency - solvency rate: cash-flow to registered capital \\ scps - staff costs per sales \\ vadps - value added per sales \\ insdarr - industry standard deviation of ARR \\ indshar - firm's share in industry sales \\ fshare - foreigners' share on registered capital \\ herfind - Herfindahl index of ownership concentration \\ quoted - dummy equals 1 if the firm's shares are registered with the Czech Securities \\ Exchange Commission (SEC)
}

\section{A.2. Macro-level Variables:}

sentim - regional investor sentiment defined as the previous year's average of the monthly sums of three dummy variables, each of the dummies equaling to 1 if the monthly return on the Czech, Polish or Hungarian stock index respectively goes above its long-term average monthly return.

sentimq - regional investor sentiment for firms with registered shares at the Czech SEC, i.e. sentim multiplied by the dummy quoted. The dummy is based on information from the Aspekt database.

linta - labor intensity in a stakeholder's home country, based on the median firm's labor costs per value added ratio in a country's NACE D sector (manufacturing). For each firm we take the stake-size-weighted average of the ratios by different stakeholders. Data come from Eurostat.

ecra - average employee compensation. Compensation of employees has two main components: (a) Wages and salaries payable in cash or in kind; (b) The value of the social contributions payable by employers: these may be actual social contributions payable by employers to Social Security schemes or to private funded social insurance schemes to secure social benefits for their employees; or imputed social contributions by employers providing unfunded social benefits. in a stakeholder's home country per average employee compensation in the Czech Republic. For each firm we take the stake-size-weighted average of the ratios by different stakeholders. Data are taken from OECD and Eurostat databases. 
dcita - statutory corporate income tax (CIT) rate in the stakeholder's home country minus the Czech CIT rate. For each firm we take the stake-size-weighted average of the differences by different stakeholders. The data source is Eurostat. 
Table 1: Descriptive Statistics of the Firm Level Variables (1997-2002)

Variable Obs Mean Std. Dev. Min Max

\begin{tabular}{lrrrrr}
\hline \hline & & & & & \\
logrta & 12470 & 11.21 & 1.33 & 2.95 & 17.37 \\
arrps & 12460 & 0.00 & 0.03 & -2.82 & 1.06 \\
lever & 12470 & 0.64 & 0.72 & -0.28 & 59.35 \\
current & 12470 & 5.25 & 83.09 & 0.00 & 5998 \\
cashfps & 12460 & -3.31 & 308.89 & -33020 & 1496 \\
solvency & 12470 & 1.13 & 41.86 & -1764 & 1248 \\
scps & 12460 & 0.34 & 6.88 & 0.00 & 481 \\
vadps & 12460 & -1.31 & 117.97 & -12402 & 1 \\
insdarr & 12470 & 39.94 & 19.09 & 0.02 & 124.75 \\
indshar & 12470 & 0.00 & 0.02 & 0.00 & 1.00 \\
fshare \% & 12470 & 9.85 & 28.36 & 0 & 100 \\
herfind & 12470 & 5885 & 3572 & 1 & 10000 \\
& & & & & \\
\hline
\end{tabular}


Table 2: Descriptive Statistics of the Firm Level Variables, Years 1997-1998 1997

\begin{tabular}{lrrrrr}
\hline Variable & Obs & Mean & Std. dev. & Min & Max \\
& & & & & \\
\hline \hline & & & & & \\
logrta & 2204 & 11.05 & 1.15 & 7.16 & 16.02 \\
arrps & 2202 & 0.00 & 0.02 & -0.25 & 1.06 \\
lever & 2204 & 0.72 & 0.35 & 0.00 & 5.08 \\
current & 2204 & 3.03 & 20.43 & 0.00 & 686.97 \\
cashfps & 2202 & 0.86 & 31.88 & -69.43 & 1361 \\
solvency & 2204 & 2.54 & 43.12 & -313.32 & 1024 \\
scps & 2202 & 0.30 & 6.11 & 0.00 & 286.14 \\
vadps & 2202 & 0.02 & 4.95 & -167.93 & 1.00 \\
insdarr & 2204 & 36.25 & 8.87 & 0.27 & 45.34 \\
indshar & 2204 & 0.00 & 0.00 & 0.00 & 0.11 \\
fshare \% & 2204 & 8.53 & 26.53 & 0 & 100 \\
herfind & 2204 & 5392 & 3587 & 1 & 10000 \\
& & & & & \\
\hline
\end{tabular}

1998

\begin{tabular}{lrrrrr}
\hline Variable & Obs & Mean & Std. dev. & Min & Max \\
& & & & & \\
\hline \hline & & & & & \\
logrta & 2338 & 10.97 & 1.24 & 2.95 & 15.39 \\
arrps & 2336 & 0.00 & 0.06 & -2.82 & 0.06 \\
lever & 2338 & 0.70 & 0.65 & -0.28 & 18.83 \\
current & 2338 & 6.03 & 68.88 & 0.00 & 1970 \\
cashfps & 2336 & -3.60 & 185.97 & -8966 & 618.18 \\
solvency & 2338 & 0.99 & 34.04 & -601.75 & 311.25 \\
scps & 2336 & 0.18 & 0.66 & 0.00 & 24.67 \\
vadps & 2336 & 0.05 & 4.37 & -192.08 & 0.99 \\
insdarr & 2338 & 34.20 & 8.02 & 1.96 & 45.79 \\
indshar & 2338 & 0.00 & 0.00 & 0.00 & 0.11 \\
fshare \% & 2338 & 9.22 & 27.61 & 0 & 100 \\
herfind & 2338 & 5796 & 3613 & 1 & 10000 \\
& & & & & \\
\hline
\end{tabular}


Table 3: Descriptive Statistics of the Firm Level Variables, Years 1999-2000 1999

\begin{tabular}{lrrrrr}
\hline Variable & Obs & Mean & Std. dev. & Min & Max \\
& & & & & \\
\hline \hline & & & & & \\
logrta & 2757 & 11.16 & 1.35 & 5.17 & 17.07 \\
arrps & 2756 & 0.00 & 0.01 & -0.47 & 0.07 \\
lever & 2757 & 0.66 & 1.21 & -0.01 & 59.35 \\
current & 2757 & 8.55 & 160.63 & 0.01 & 5998 \\
cashfps & 2756 & -12.07 & 629.16 & -33020 & 460.41 \\
solvency & 2757 & 1.57 & 51.01 & -1422 & 1248 \\
scps & 2756 & 0.26 & 3.48 & 0.00 & 182.00 \\
vadps & 2756 & -1.50 & 83.75 & -4385 & 1.00 \\
insdarr & 2757 & 62.40 & 22.82 & 0.02 & 107.37 \\
indshar & 2757 & 0.00 & 0.02 & 0.00 & 0.69 \\
fshare \% & 2757 & 9.37 & 27.74 & 0 & 100 \\
herfind & 2757 & 5900 & 3580 & 1 & 10000 \\
& & & & & \\
\hline
\end{tabular}

2000

\begin{tabular}{lrrrrr}
\hline Variable & Obs & Mean & Std. dev. & Min & Max \\
& & & & & \\
\hline \hline & & & & & \\
logrta & 2853 & 11.26 & 1.36 & 5.99 & 17.34 \\
arrps & 2851 & 0.00 & 0.02 & -0.91 & 0.01 \\
lever & 2853 & 0.60 & 0.53 & -0.19 & 14.25 \\
current & 2853 & 3.74 & 21.89 & 0.00 & 849.23 \\
cashfps & 2851 & -0.10 & 65.37 & -2889 & 1496 \\
solvency & 2853 & 0.53 & 43.66 & -1764 & 390.20 \\
scps & 2851 & 0.42 & 8.47 & 0.00 & 432.30 \\
vadps & 2851 & 0.01 & 5.22 & -222.60 & 0.99 \\
insdarr & 2853 & 37.43 & 9.57 & 0.28 & 75.67 \\
indshar & 2853 & 0.00 & 0.02 & 0.00 & 1.00 \\
fshare \% & 2853 & 10.26 & 28.82 & 0 & 100 \\
herfind & 2853 & 6189 & 3531 & 1 & 10000 \\
& & & & & \\
\hline
\end{tabular}


Table 4: Descriptive Statistics of the Firm Level Variables, Years 2001-2002 2001

\begin{tabular}{lrrrrr}
\hline Variable & Obs & Mean & Std. dev. & Min & Max \\
& & & & & \\
\hline \hline & & & & & \\
logrta & 1773 & 11.54 & 1.42 & 3.56 & 16.83 \\
arrps & 1772 & 0.00 & 0.00 & -0.16 & 0.02 \\
lever & 1773 & 0.53 & 0.36 & -0.05 & 4.09 \\
current & 1773 & 4.44 & 28.75 & 0.00 & 1123 \\
cashfps & 1772 & -0.85 & 37.47 & -1567 & 89.29 \\
solvency & 1773 & 0.57 & 32.73 & -790.35 & 381.51 \\
scps & 1772 & 0.40 & 4.61 & 0.00 & 129.00 \\
vadps & 1772 & -0.04 & 7.40 & -296.43 & 0.99 \\
insdarr & 1773 & 24.83 & 13.04 & 0.03 & 124.75 \\
indshar & 1773 & 0.00 & 0.02 & 0.00 & 0.79 \\
fshare \% & 1773 & 11.66 & 30.57 & 0 & 100 \\
herfind & 1773 & 6076 & 3508 & 2 & 10000 \\
& & & & & \\
\hline
\end{tabular}

2002

\begin{tabular}{lrrrrr} 
Variable & Obs & Mean & Std. dev. & Min & Max \\
& & & & & \\
\hline \hline & & & & & \\
logrta & 545 & 11.82 & 1.39 & 7.62 & 17.37 \\
arrps & 543 & 0.00 & 0.00 & -0.01 & 0.00 \\
lever & 545 & 0.49 & 0.44 & -0.01 & 5.59 \\
current & 545 & 4.70 & 13.54 & 0.04 & 191.28 \\
cashfps & 543 & 0.61 & 19.87 & -162.04 & 432.00 \\
solvency & 545 & -1.18 & 31.20 & -435.66 & 108.23 \\
scps & 543 & 1.10 & 20.63 & 0.00 & 481.00 \\
vadps & 543 & -22.67 & 532.23 & -12402 & 0.96 \\
insdarr & 545 & 28.23 & 20.41 & 0.08 & 71.95 \\
indshar & 545 & 0.01 & 0.06 & 0.00 & 0.67 \\
fshare \% & 545 & 12.42 & 31.32 & 0 & 100 \\
herfind & 545 & 5982 & 3505 & 9 & 10000
\end{tabular}


Table 5: International Investor Sentiment year Czech R. Hungary Poland sentim

\begin{tabular}{lllll}
\hline \hline & & & & \\
1995 & .33 & .33 & .50 & 1.17 \\
1996 & .42 & .42 & .42 & 1.25 \\
1997 & .58 & .83 & .75 & 2.17 \\
1998 & .50 & .58 & .42 & 1.50 \\
1999 & .58 & .58 & .67 & 1.83 \\
2000 & .75 & .58 & .83 & 2.17 \\
2001 & .33 & .25 & .33 & .92 \\
2002 & .42 & .42 & .33 & 1.17 \\
2003 & .67 & .50 & .50 & 1.67 \\
& & & & \\
\hline
\end{tabular}

Note:

A dummy variable for a given month and country equals 1 if the the monthly market return is higher than the long-term average (1993-2003). Sentim is the previous year's average of monthly sums of the three dummies for the Czech Republic, Hungary, and Poland. 
Table 6: Labor Costs per Value Added in Manufacturing

\begin{tabular}{lccc} 
& 1998 & 2000 & 2002 \\
\hline \hline Belgium & .62 & .61 & .63 \\
Czech Republic & .57 & .51 & .54 \\
Denmark & .69 & .68 & .68 \\
Germany & .72 & .73 & .72 \\
Greece & .4 & .38 & .37 \\
Spain & .64 & .65 & .68 \\
France & .60 & .60 & .59 \\
Italy & .55 & .55 & .56 \\
Luxembourg & .59 & .61 & .63 \\
Hungary & .52 & .55 & .54 \\
Netherlands & .59 & .59 & .63 \\
Austria & .63 & .57 & .56 \\
Poland & .63 & .61 & .6 \\
Portugal & .60 & .61 & .63 \\
Slovakia & .54 & .48 & .53 \\
Finland & .53 & .51 & .57 \\
Sweden & .61 & .61 & .66 \\
United Kingdom & .69 & .81 & .81 \\
& & & \\
\hline
\end{tabular}

Note:

Based on the median firm in NACE sector D (manufacturing) 
Table 7: Employee Compensation Rate (Foreign Country/ Czech Republic)

\begin{tabular}{llllllllll}
1995 & 1996 & 1997 & 1998 & 1999 & 2000 & 2001 & 2002 & 2003 & 2004 \\
\hline
\end{tabular}

\begin{tabular}{|c|c|c|c|c|c|c|c|c|c|c|}
\hline Australia & 4.32 & 3.51 & 3.84 & 3.77 & 3.01 & 3.73 & 3.24 & 2.91 & 2.57 & 2.76 \\
\hline Austria & 6.02 & 5.13 & 5.04 & 5.28 & 4.70 & 4.68 & 4.40 & 4.01 & 3.77 & 3.60 \\
\hline Belgium & 7.17 & 6.14 & 6.02 & 6.25 & 5.69 & 5.62 & 5.29 & 4.88 & 4.59 & 4.43 \\
\hline Canada & 4.64 & 3.94 & 4.10 & 4.68 & 3.71 & 4.67 & 4.51 & 4.04 & 3.20 & 3.12 \\
\hline Denmark & 6.76 & 6.14 & 5.84 & 6.10 & 5.55 & 5.62 & 5.32 & 4.83 & 4.60 & 4.40 \\
\hline Finland & 5.78 & 4.99 & 4.87 & 5.27 & 4.73 & 4.77 & 4.57 & 4.12 & 3.90 & 3.77 \\
\hline France & 6.49 & 5.57 & 5.40 & 5.59 & 5.00 & 4.94 & 4.63 & 4.21 & 3.96 & 3.81 \\
\hline Germany & 6.23 & 5.32 & 5.11 & 5.31 & 4.70 & 4.66 & 4.31 & 3.89 & 3.63 & 3.43 \\
\hline Greece & 2.28 & 2.14 & 2.27 & 2.45 & 2.30 & 2.35 & 2.25 & 2.14 & 2.04 & 2.02 \\
\hline Hungary & 1.48 & 1.14 & 1.13 & 1.19 & .94 & 1.08 & 1.08 & 1.14 & 1.18 & 1.09 \\
\hline Iceland & 5.02 & 4.56 & 4.62 & 5.44 & 5.1 & 5.99 & 5.38 & 4.44 & 4.56 & 4.23 \\
\hline Ireland & 4.71 & 4.05 & 4.10 & 4.36 & 4.05 & 4.13 & 3.96 & 3.64 & 3.41 & 3.36 \\
\hline Italy & 5.12 & 4.53 & 4.46 & 4.55 & 4.09 & 4.08 & 3.82 & 3.49 & 3.31 & 3.18 \\
\hline Japan & 8.90 & 6.95 & 6.16 & 6.31 & 5.78 & 7.43 & 6.43 & 5.13 & 4.32 & 3.75 \\
\hline Luxemb & 7.20 & 6.14 & 5.97 & 6.28 & 5.76 & 5.88 & 5.55 & 5.10 & 4.74 & 4.56 \\
\hline Mexic & 1.04 & .71 & .80 & 1.08 & .83 & 1.08 & 1.16 & 1.19 & .86 & .64 \\
\hline Netherlands & 5.00 & 4.29 & 4.18 & 4.47 & 4.05 & 4.10 & 3.90 & 3.67 & 3.48 & 3.32 \\
\hline New Zealand & 3.03 & 2.54 & 2.74 & 2.66 & 2.02 & 2.33 & 1.95 & 1.77 & 1.78 & 1.77 \\
\hline Norway & 6.75 & 5.95 & 5.90 & 6.47 & 5.46 & 6.11 & 5.86 & 5.61 & 5.83 & 4.91 \\
\hline Poland & .88 & .91 & .93 & 1.01 & .96 & 1.00 & 1.11 & 1.09 & .86 & .71 \\
\hline Portugal & 2.38 & 2.19 & 2.17 & 2.33 & 2.13 & 2.21 & 2.11 & 1.95 & 1.85 & 1.78 \\
\hline Slovak Re & .71 & .63 & .67 & .79 & .67 & .76 & .70 & .69 & .67 & .70 \\
\hline Spain & 4.17 & 3.72 & 3.67 & 3.87 & 3.48 & 3.5 & 3.32 & 3.09 & 2.97 & 2.91 \\
\hline Sweder & 6.33 & 6.06 & 6.05 & 6.32 & 5.14 & 5.93 & 5.45 & 4.67 & 4.45 & 4.36 \\
\hline Switzerland & 7.69 & 7.06 & 6.13 & 6.58 & 5.86 & 5.87 & 5.82 & 5.37 & 5.05 & 4.45 \\
\hline Turkey & .73 & .73 & .81 & .82 & .77 & .76 & .84 & .49 & .42 & .47 \\
\hline United Kir & 5.11 & 4.17 & 4.67 & 5.59 & 4.87 & 5.66 & 5.42 & 5.1 & 4.56 & 4.15 \\
\hline United States & 6.07 & 5.02 & 5.14 & 6.27 & 5.41 & 6.54 & 6.60 & 6.37 & 5.10 & 4.13 \\
\hline
\end{tabular}

Note:

Source - OECD 
Table 8: Statutory Corporate Income Tax Rates (\%)

\begin{tabular}{llllllllll}
1995 & 1996 & 1997 & 1998 & 1999 & 2000 & 2001 & 2002 & 2003 & 2004 \\
\hline
\end{tabular}

$\begin{array}{lllllllllll}\text { Austria } & 34 & 34 & 34 & 34 & 34 & 34 & 34 & 34 & 34 & 34 \\ \text { Belgium } & 40.2 & 40.2 & 40.2 & 40.2 & 40.2 & 40.2 & 40.2 & 40.2 & 34 & 34 \\ \text { Denmark } & 34 & 34 & 34 & 34 & 32 & 32 & 30 & 30 & 30 & 30 \\ \text { Finland } & 25 & 28 & 28 & 28 & 28 & 29 & 29 & 29 & 29 & 29 \\ \text { France } & 36.7 & 36.7 & 36.7 & 41.7 & 40 & 36.7 & 36.4 & 35.4 & 35.4 & 35.4 \\ \text { Germany } & 56.8 & 56.7 & 56.7 & 56 & 51.6 & 51.6 & 38.3 & 38.3 & 39.6 & 38.3 \\ \text { Greece } & 40 & 40 & 40 & 40 & 40 & 40 & 37.5 & 35 & 35 & 35 \\ \text { Ireland } & 40 & 38 & 36 & 32 & 28 & 24 & 20 & 16 & 12.5 & 12.5 \\ \text { Italy } & 52.2 & 53.2 & 53.2 & 41.3 & 41.3 & 41.3 & 40.3 & 40.3 & 38.3 & 37.3 \\ \text { Luxembourg } & 40.9 & 40.9 & 39.3 & 37.5 & 37.5 & 37.5 & 37.5 & 30.4 & 30.4 & 30.4 \\ \text { Netherlands } & 35 & 35 & 35 & 35 & 35 & 35 & 35 & 34.5 & 34.5 & 34.5 \\ \text { Portugal } & 39.6 & 39.6 & 39.6 & 37.4 & 37.4 & 35.2 & 35.2 & 33 & 33 & 27.5 \\ \text { Spain } & 35 & 35 & 35 & 35 & 35 & 35 & 35 & 35 & 35 & 35 \\ \text { Sweden } & 28 & 28 & 28 & 28 & 28 & 28 & 28 & 28 & 28 & 28 \\ \text { United Kingdom } & 33 & 33 & 31 & 31 & 30 & 30 & 30 & 30 & 30 & 30 \\ \text { Cyprus } & 25 & 25 & 25 & 25 & 25 & 29 & 28 & 28 & 15 & 15 \\ \text { Czech Republic } & 41 & 39 & 39 & 35 & 35 & 31 & 31 & 31 & 31 & 28 \\ \text { Estonia } & 26 & 26 & 26 & 26 & 26 & 26 & 26 & 26 & 26 & 26 \\ \text { Hungary } & 19.6 & 19.6 & 19.6 & 19.6 & 19.6 & 19.6 & 19.6 & 19.6 & 19.6 & 17.7 \\ \text { Latvia } & 25 & 25 & 25 & 25 & 25 & 25 & 25 & 22 & 19 & 15 \\ \text { Lithuania } & 29 & 29 & 29 & 29 & 29 & 24 & 24 & 15 & 15 & 15 \\ \text { Malta } & 35 & 35 & 35 & 35 & 35 & 35 & 35 & 35 & 35 & 35 \\ \text { Poland } & 40 & 40 & 38 & 36 & 34 & 30 & 28 & 28 & 27 & 19 \\ \text { Slovakia } & 40 & 40 & 40 & 40 & 40 & 29 & 29 & 25 & 25 & 19 \\ \text { Slovenia } & 25 & 25 & 25 & 25 & 25 & 25 & 25 & 25 & 25 & 25\end{array}$

Note:

Source - European Comission 
Table 9: Im - Pesaran - Shin Tests for Panel Unit Roots Variable trend $t$-bar $Z_{t-b a r} \quad \mathrm{P}$-value

\begin{tabular}{lcrrr}
\hline \hline & & & & \\
fshare & no & -3.06 & -20.15 & 0.00 \\
fshare & yes & -0.93 & -14.75 & 1.00 \\
herfind & no & -1.40 & 1.09 & 0.86 \\
herfind & yes & -2.53 & 4.30 & 0.00 \\
insdarr & no & -2.37 & -11.26 & 0.00 \\
insdarr & yes & -2.27 & -1.16 & 0.12 \\
& & & & \\
\hline
\end{tabular}

Note:

$t$-bar mean of the individual Dickey-Fuller t-statistics of each unit in the panel

$Z_{t-b a r} \sim \mathrm{N}(0,1)$ under the null hypothesis of non-stationarity

Table 10: Hurlin Tests for Homogeneous Non-Causality in Panel Data

$$
\begin{array}{lll}
H_{0} & Z_{N T}^{H N C} & \text { P-value }
\end{array}
$$

herfind does not Granger cause fshare $\quad-5.27 \quad 0.00$

fshare does not Granger cause herfind $\quad 1.539 \mathrm{e}+14 \quad 0.00$

insdarr does not Granger cause fshare $\quad-4.13 \quad 0.00$

fshare does not Granger cause insdarr $\quad-6.00 \quad 0.00$

Table 11: Specification Tests

$H_{0} \quad H_{A} \quad$ Hausman's $\chi^{2} \quad$ P-value Endogenous Vars

\begin{tabular}{llrll}
\hline \hline & & & & \\
LM-RE & LM-FE & 241.88 & 0.00 & $\mathrm{~N} / \mathrm{A}$ \\
LM-FE & LM-FE-2SLS & 15.08 & 0.02 & herfind, insdarr \\
LM-FD & LM-FD-2SLS & 345.65 & 0.00 & Nerfind, insdarr \\
LM-FE & LM-FE-AR & & & \\
& & & \\
\hline
\end{tabular}


Table 12: OLS and Fixed Effects Models
LM-OLS
LM-FE
LM-FE-2SLS

(1)

(2)

(3)

$\begin{array}{llll}\text { year } & .174^{*} & .782^{* * *} & .892^{* * *} \\ \text { sentim } & -.865^{* * *} & .519^{* * *} & .689^{* * *} \\ \text { linta } & -6.849^{*} & 30.53^{* * *} & 41.854^{* * *} \\ \text { ecra } & 21.072^{* * *} & 18.399^{* * *} & 18.1^{* * *} \\ \text { dcita } & .272^{* * *} & .123^{* * *} & .15^{* * *} \\ \text { insdarr } & .014^{* *} & .03^{* * *} & .06^{* * *} \\ \text { scps } & -.013 & .009 & -.009 \\ \text { vadps } & -.0002 & -.007 & -.019 \\ \text { arrps } & 1.152 & .478 & 1.571 \\ \text { lever } & .218 & -.098 & -.085 \\ \text { current } & .0009 & .0004 & .0003 \\ \text { cashfps } & .0001 & -.0005 & -.0005 \\ \text { solvency } & -.0005 & -.002^{*} & -.002^{*} \\ \text { logrta } & .139 & .383^{*} & .374^{*} \\ \text { herfind } & .0007^{* * *} & .0004^{* * *} & .0008^{* *} \\ \text { indshar } & 14.033^{* * *} & 23.141^{* * *} & 37.169^{* * *} \\ \text { cons } & -369.182^{*} & -1604.679^{* * *} & -1834.043^{* * *} \\ \text { rho } & .858^{* * *} & .066^{* * *} & .034^{* * *} \\ \text { Obs. } & 12460 & 12460 & 11138 \\ \text { R } & .825 & .8205 & .8084 \\ \text { F-stat. } & 3665.953^{* * *} & 866.218^{* * *} & 45109.40^{* * *} \\ & & & \end{array}$

Note: Stars denote significance at 90, 95, and 99\%. 
Table 13: First Differences Models

\begin{tabular}{|c|c|c|}
\hline & $\begin{array}{c}\text { LM-FD } \\
(1)\end{array}$ & $\begin{array}{c}\text { LM-FD-2SLS } \\
(2)\end{array}$ \\
\hline D.sentim & $.321^{* *}$ & $.496^{* * *}$ \\
\hline D.linta & $16.519^{* * *}$ & $24.201^{* * *}$ \\
\hline D.ecra & $19.322^{* * *}$ & $19.249^{* * *}$ \\
\hline D.dcita & $-.212^{* * *}$ & $-.179^{* * *}$ \\
\hline D.insdarr & $.024^{* * *}$ & $.038^{* * *}$ \\
\hline D.scps & .022 & .036 \\
\hline D.vadps & .016 & .023 \\
\hline D.arrps & -1.002 & -1.489 \\
\hline D.lever & -.138 & -.113 \\
\hline D.current & .0003 & .0002 \\
\hline D.cashfps & -.0003 & -.0007 \\
\hline D.solvency & -.001 & -.001 \\
\hline D.logrta & .054 & .075 \\
\hline D.herfind & $.0004^{* * *}$ & .0001 \\
\hline D.indshar & 2.885 & 4.207 \\
\hline cons & $.549^{* * *}$ & $.673^{* * *}$ \\
\hline Obs. & 7261 & 6424 \\
\hline $\mathrm{R}^{2}$ & .673 & .8169 \\
\hline F-stat. & $996.165^{* * *}$ & $13232.23^{* * *}$ \\
\hline
\end{tabular}

Note: Stars denote significance at 90, 95, and 99\%. 
Table 14: Panel Data Logit, Probit, and Tobit Models

\begin{tabular}{lccc} 
& Pro-RE & Lo-FE & To-RE \\
& $(1)$ & $(2)$ & $(3)$ \\
\hline \hline & & & \\
year & $.25^{* * *}$ & .003 & $6.066^{* * *}$ \\
sentim & -.057 & -.105 & 1.665 \\
linta & .367 & -2.881 & $68.98^{* * *}$ \\
ecra & $2.884^{* * *}$ & $1.703^{* * *}$ & $36.266^{* * *}$ \\
dcita & .027 & $.197^{*}$ & $-.335^{* * *}$ \\
insdarr & $.011^{* *}$ & .019 & $.13^{* * *}$ \\
scps & -.01 & 13.739 & -.235 \\
vadps & -.00009 & 1.162 & -.006 \\
arrps & .505 & 270.995 & 7.389 \\
lever & .006 & 2.075 & .108 \\
current & .00006 & .012 & .001 \\
cashfps & .0001 & 1.105 & .001 \\
solvency & 0 & $-.016^{*}$ & $-.021^{* *}$ \\
logrta & $.149^{*}$ & .539 & .181 \\
herfind & $.0007^{* * *}$ & $.0005^{* * *}$ & $.006^{* * *}$ \\
indshar & $5.889^{* *}$ & $90.348^{*}$ & $92.342^{* * *}$ \\
cons & $-517.509^{* * *}$ &. & $-12326.7^{* * *}$ \\
Obs. & 12460 & 399 & 12460 \\
Chi ${ }^{2}$ (Wald, LR, Wald) & $286.94^{* * *}$ & $241.47^{* * *}$ & $6602.78^{* * *}$ \\
& & & \\
\hline
\end{tabular}

Note: Stars denote significance at 90, 95, and $99 \%$. 
Table 15: Cox's Proportional Hazard Model

PH-Cox

(1)

$\begin{array}{lc}\text { insdarr } & .008^{* *} \\ \text { scps } & .007 \\ \text { vadps } & .002 \\ \text { arrps } & -.524 \\ \text { lever } & -.111 \\ \text { current } & -.012 \\ \text { cashfps } & .0008 \\ \text { solvency } & -.0004 \\ \text { logrta } & .448^{* * *} \\ \text { herfind } & .0001^{* * *} \\ \text { indshar } & .923 \\ \text { cons } & . \\ \text { Obs. } & 13973 \\ \text { Wald Chi }{ }^{2} & 259.86^{* * *} \\ \end{array}$

Note: Stars denote significance at 90, 95, and 99\%. 
Table 16: Truncated Dependent Variable Model for Foreign Stakeholders Truncated dependant variable model (1)

$\begin{array}{lc}\text { sentim } & -.432 \\ \text { lintensi } & -.617 \\ \text { ecr } & -.01 \\ \text { dcit } & .013 \\ \text { insdarr } & .047^{* * *} \\ \text { scps } & .061 \\ \text { vadps } & -.089 \\ \text { arrps } & -29.954 \\ \text { lever } & -.987 \\ \text { current } & -.00009 \\ \text { cashfps } & -.002 \\ \text { solvency } & .002 \\ \text { logrta } & -.263 \\ \text { herfind } & .009^{* * *} \\ \text { indshar } & -.187 \\ \text { cons } & 10.286^{*} \\ \text { Obs. } & 1877 \\ \text { Wald Chi }{ }^{2} & 7518.02^{* * *}\end{array}$

Note: Stars denote significance at 90, 95, and $99 \%$. 
Figure 1: Histogram, Accounting Rate of Return

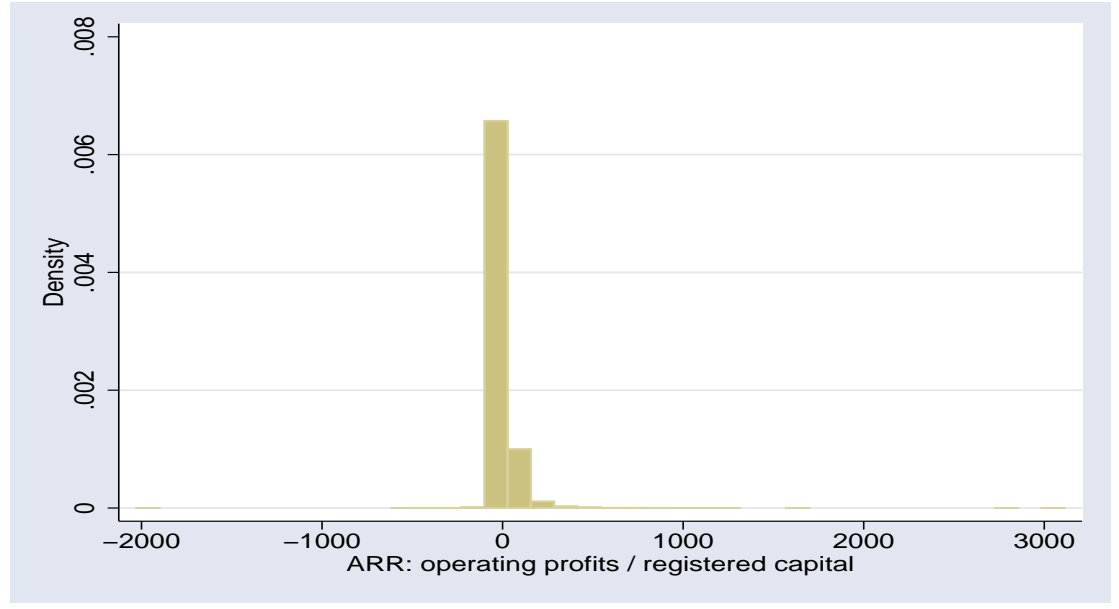

Figure 2: Histogram, Ownership by Foreigners, \%

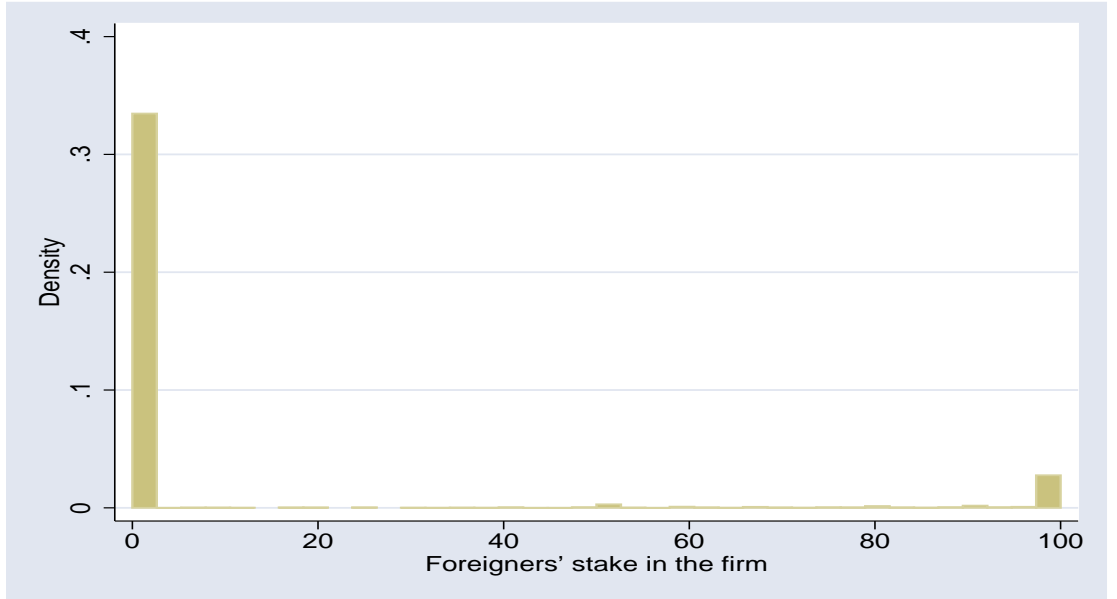


Figure 3: Histogram, Ownership by Foreigners, Positive Values, \%

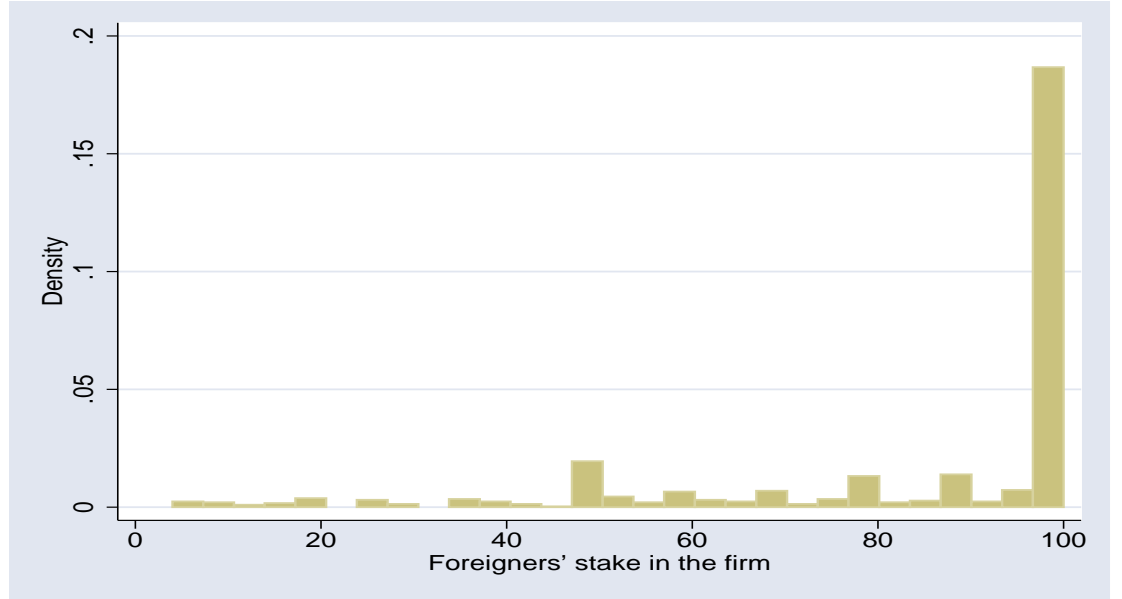


Individual researchers, as well as the on-line and printed versions of the CERGE-EI Working Papers (including their dissemination) were supported from the following institutional grants:

- Center of Advanced Political Economy Research [Centrum pro pokročilá politicko-ekonomická studia], No. LC542, (2005-2009),

- Economic Aspects of EU and EMU Entry [Ekonomické aspekty vstupu do Evropské unie a Evropské měnové unie], No. AVOZ70850503, (2005-2010);

- Economic Impact of European Integration on the Czech Republic [Ekonomické dopady evropské integrace na ČR], No. MSM0021620846, (2005-2011);

Specific research support and/or other grants the researchers/publications benefited from are acknowledged at the beginning of the Paper.

(c) Peter Tóth, Petr Zemčík, 2006

All rights reserved. No part of this publication may be reproduced, stored in a retrieval system or transmitted in any form or by any means, electronic, mechanical or photocopying, recording, or otherwise without the prior permission of the publisher.

Published by

Charles University in Prague, Center for Economic Research and Graduate Education (CERGE) and

Economics Institute (EI), Academy of Sciences of the Czech Republic

CERGE-El, Politických vězňů 7, 11121 Prague 1, tel.: +420 224005 153, Czech Republic.

Printed by CERGE-EI, Prague

Subscription: CERGE-El homepage: http://www.cerge-ei.cz

Editors: Directors of CERGE and EI

Managing editors: Deputy Directors for Research of CERGE and EI

ISSN 1211-3298

ISBN 80-7343-089-4 (Univerzita Karlova v Praze, CERGE)

ISBN 80-7344-078-4 (Národohospodářský ústav AV ČR, Praha) 
CERGE-EI

P.O.BOX 882

Politických vězňů 7

11121 Praha 1

Czech Republic http://www.cerge-ei.cz 